\title{
PENINGKATAN PENGETAHUAN GIZI SEIMBANG DAN MITOS SEPUTAR GIZI PADA KELUARGA PRA-SEJAHTERA DI KELURAHAN DELIMA PEKANBARU
}

\author{
Saipul Al Sukri, Novfitri Syuryadi, Yanti Ernalia \\ Universitas Islan Negeri Sultan Syarif Kasim Riau \\ saipul.alsukri@gmail.com
}

\begin{abstract}
The wrong dietary pattern will cause various diseases. Health and nutrition counseling is one of a variety of ways to improve knowledge. The advice can improve nutrition knowledge to mothers, which is will impact on changing the nutritional food their family members, including their toddlers. This community service carried out at Kelurahan Delima, Kecamatan Tampan, Pekanbaru. The mother's decision as a participant partner in this service was because she was a family member who prepared food for their family. This community service activity carried out with counseling methods by leaflets, demonstrations, and assessments with anthropometric methods. Other than that, a pre-test and post-test evaluation carried out to understanding balanced nutrition by them. This activity can improve their knowledge about a balanced diet, the results of the post-test partners evidence this.
\end{abstract}

Keywords: Counseling, Balanced Nutrition, Family.

\begin{abstract}
Abstrak
Pola makan yang salah akan berujung pada datangnya berbagai penyakit. Penyuluhan kesehatan merupakan satu diantara beragam cara untuk menambah pengetahuan. Penyuluhan dapat meningkatkan pengetahuan gizi kepada ibu-ibu yang pada akhirnya akan berdampak kepada perubahan status gizi di anggota keluarga. Pengabdian kepada masyarakat ini dilakukan di kelurahan Delima kecamatan Tampan. Ibu dijadikan sebagai mitra peserta dalam pengabdian ini karena ibu adalah anggota keluarga yang menyiapkan asupan makanan bagi keluarga. Kegiatan pengabdian dilaksanakan dengan metode penyuluhan dengan bantuan leaflet, demonstrasi,asesmen dengan metode antropometri. Selain itu juga dilakukan penilaian pretest dan posttest mengenai pemahaman gizi seimbang pada mitra peserta pengabdian. Pengabdian berjalan dengan baik.Kegiatan yang dilakukan dapat menambah pengetahuan masyarakat tentang gizi seimbang hal ini dibuktikan dengan hasil baik dari post-test mitra.
\end{abstract}

Kata kunci: Penyuluhan, Gizi Seimbang, Keluarga.

PENDAHULUAN

MARTABE : Jurnal Pengabdian Masyarakat $\mid 108$ 
Setiap makhluk yang hidup pasti memerlukan makanan. Makanan tidak hanya berfungsi mempertahankan kelangsungan hidup, lebih jauh makanan dapat menjadi sumber tenaga, tumbuh kembang, mempertahankan ketahanan tubuh dan beberapa makanan juga mampu menghindari dan mengobati kita dari serangan penyakit. Namun sekarang dengan ketersediaan jumlah makanan saja ternyata tidak lantas mengurangi permasalahan hidup. Justru dengan kuantitas makanan yang melimpah dengan perkembangan teknologi malah menimbulkan persoalan baru dengan menurunnya kualitas makan yang tersedia (Khensun, 2009). Pola makanan yang salah juga dapat menimbulkan persoalan kesehatan (Cordobo, 2010). Keputusan Menteri Kesehatan (2003) tentang Persyaratan Hygiene Sanitasi mengatakan bahwa makanan yang sehat adalah makanan dengan sumber yang baik, pengolahan yang benar dan penyimpanan yang betul. Persyaratan ini merupakan hal yang sangat penting, sebab makanan yang dimakan bukan saja harus memenuhi gizi dan bentuk yang menarik tetapi juga harus aman dari bahan-bahan kima dan mikro organisme yang dapat menyebabkan munculnya penyakit. Dalam memilih makanan yang baik perlu memperhatikan asupan gizi. Menurut Almatsier (2004) mengatakan zat gizi adalah senyawa kimia yang diperlukan tubuh untuk melakukan fungsinya, antara lain untuk menghasilkan energi, membangun dan memelihara jaringan serta mengatur proses-proses kehidupan.

Hasil dari riset kesehatan dasar yang dilakukan oleh kementrian kesehatan pada tahun 2018 menunjukkan terdapat $17,7 \%$ usia dibawah 5 tahun yang mengalami masalah gizi di Indonesia. Informasi dari Badan Pusat Statistik (BPS) juga menunjukkan hasil yang tidak mengembirakan dimana 1 dari 4 anak di Indonesia mengalami Stunting pada tahun 2018. BPS juga mencatat, prevelensi balita yang mengalami Stunting di Indonesia masih cukup tinggi jika dibandingkan negara dengan pendapatan rendah lainnya.Saat ini masalah gizi sering dikenal dengan Triple Burden yaitu masalah gizi lebih, masalah gizi kurang, dan stunted. Masalah gizi (Malnutrition) ini akan menimbulkan dampak menurunnya kualitas sumber daya manusia indonesia dan berpotensi terhadap penyakit menular dan penyakit tidak menular yang saat ini berkembang di Indonesia. Terdapat dua penyebab langsung yang berpengaruh terhadap terjadinya masalah gizi yaitu asupan dan penyakit infeksi.Gizi seimbang merupakan pedoman dalam mengonsumsi makanan yang sehat, aman untuk mempertahankan gizi yang optimal.Gizi seimbang adalah makanan yang dikonsumsi oleh individu seharihari yang beraneka ragam dan memenuhi 5 kelompok gizi dalam jumlah yang cukup tidak kurang dan tidak lebih (Dirjen BKM, 2002).

Pengetahuan gizi seseorang merupakan salah satu faktor yang dapat memengaruhi konsumsi pangan dan status gizinya. Pengetahuan gizi seseorang didukung oleh latar belakang pendidikannya. Rendahnya tingkat pendidikan akan berakibat kepada keterbatasan informasi dan penanganan masalah gizi dan kesehatan. Ibu-ibu di Indonesia bertanggungjawab dalam belanja pangan, mengatur menu keluarga, mendistribusikan makanan. Pengetahuan gizi ibu akan sangat berpengaruh terhadap keadaan gizi keluarga (Suhardjo, 2005).

Penyuluhan merupakan suatu yang direkomendasikan guna 
meningkatkan pengetahuan gizi seimbang pada ibu-ibu (soekirman, 2002). Hal ini sejalan dengan penelitian yang dilakukan oleh Tursiani (2010) yang menemukan bahwa Penyuluhan dapat meningkatkan pengetahuan gizi kepada ibu-ibu. Pengetahuan tentang gizi yang baik pada akhirnya akan berdampak kepada perubahan status gizi di anggota keluarga tak terkecuali pada balita mereka. Penyuluhan sebagai proses perubahan perilaku tidak mudah, hal ini menuntut suatu persiapan yang panjang dan pengetahuan yang memadai bagi penyuluh maupun sasarannya. Penyuluhan dapat diartikan sebagai proses dalam merubah perilaku manusia. Selain membutuhkan waktu yang cukup lama, penyuluhan juga membutuhkan perencanaan yang matang, terarah dan berkesinambungan (Lucie, 2005). Menurut Notoatmodjo (2003), untuk merubah perilaku, seseorang harus mengikuti tahap-tahap proses perubahan, pengetahuan (knowledge), sikap (attitude) dan praktek (pratice).

Selain masalah diatas, saat ini banyak masyarakat yang beranggapan bahwa asupan gizi yang baik itu harus mahal.Persepsi yang keliru lainnya adalah soal mitos-mitos tentang kesehatan dan gizi. Mengingat tingginya resiko keluarga dengan pendapatan rendah dalam pengetahuan tentang gizi, tingginya angka stunting dan hasil pengamatan yang dilakukan tim pengabdi di lokasi tersebut belum pernah dilakukan penyuluhan tentang makanan sehat dan gizi seimbang, maka perlu dilakukan upaya untuk meningkatkan pengetahuan tersebut. Berdasarkan hal diatas maka pengabdi tertarik untuk melakukan kegiatan pengabdian dengan tema "Peningkatan pengetahuan gizi seimbang dan mitos seputar gizi pada keluarga pra-sejahtera di Kelurahan Delima Kota Pekanbaru."

\section{METODE PELAKSANAAN}

Pelaksanaan kegiatan pengabdian ini adalah melalui metode penyuluhan dengan bantuan leaflet, demonstrasi,asesmen dengan metode antropometri, yang disertai dengan penilaian pre test dan post test mengenai pemahaman gizi seimbang pada mitra peserta pengabdian. Tahapan pelaksanaan kegiatan Pengabdian pada Masyarakat ini adalah sebagai berikut :

1. Pengukuran antropometri berat badan menggunakan timbangan digital dan pengukuran TB peserta menggunakan mikrotois untuk mengetahu Indeks Massa Tubuh (IMT) status gizi peserta (ibu rumah tangga) dan memberikan edukasi gizi sesuai dengan konsultasi gizi mereka.

2. Pre-test yang berisi 15 soal mengenai gizi seimbang pada peserta.

3. Memberikan Edukasi gizi seimbang dan informasi mengenai mitos gizi yang salah pada masyarakat melalui metode ceramah, demonstrasi poster, film, dan leaflet, serta peragaan ukuran tangan dalam penentuan porsi makanan pada pemenuhan gizi seimbang anggota keluarga.

4. Melakukan sesi tanya jawab dan kuis sekaligus memberikan doorprize pada peserta.

5. Melakukan post-test diakhir kegiatan pengabdian.

\section{HASIL DAN PEMBAHASAN}

Kegiatan Pengabdian ini dilaksanakan secara tatap muka dan merupakan upaya dalam berbagi ilmu dan informasi tentang kesehatan masyarakat melalui peningkatan 
pengetahuan gizi seimbang. Pedoman gizi seimbang merupakan program dari Kementerian Kesehatan dengan 10 pesan gizi mencakup mensyukuri dan menikmati anekaragam makanan yang ada, konsumsi sayur dan buah, konsumsi lauk tinggi protein, konsumsi anekaragam makanan pokok, membatasi gula garam lemak, membiasakan sarapan, cukup konsumsi air putih, label makanan, cuci tangan pakai sabun, dan melakukan aktivitas fisik serta mempertahankan berat badan normal.

Masyarakat sasaran kegiatan ini adalah ibu-ibu penerima PKH RW 002 Kelurahan Delima Kecamatan Tampan kota Pekanbaru. Masyarakat ini merupakan masyarakat prasejahtera sehingga perlu mendapatkan tambahan pengetahuan bagaimana pemenuhan gizi seimbang tanpa harus mengeluarkan danabanyak sesuai dengan pesan gizi seimbang. Tim pengabdi memulai kegiatan dengan menghubungi ketua RW dan pendamping $\mathrm{PKH}$ setempat untuk menjelaskan tujuan pengabdian dan manfaat yang dapat diperoleh dari masyarakat sasaran.

Kegiatan ini selesai dilaksanakan dengan jumlah masyarakat sasaran sebanyak 26 orang.Untuk melihat peningkatan pengetahuan dari kegiatan yang dilakukan maka dilakukan pre-test dan post-test tentang pengetahuan gizi seimbang. Selain itu dilakukan juga sesi tanya jawab terkait gizi seimbang dan fakta atau mitos terkait gizi dan kesehatan. Beberapa pertanyaan yang muncul dari masyarakat sasaran adalah apakah cukup kenyang dengan mengonsumsi makanan sesuai pedoman gizi seimbang dan isi piringku, snack yang baik untuk anak seperti apa, apakah mengonsumsi sayur bisa menyebabkan asam urat, apakah kuning telur mengandung kolesterol dan seberapa banyak konsumsi telur yang diperbolehkan, contoh menu sarapan dan jam berapa sebaiknya sarapan. Seluruh pertanyaan yang dilontarkan oleh masyarakat sasaran dapat dijawab dengan baik.

Selain itu tim pengabdi juga menekankan bahwa sangat penting untuk mengonsumsi makanan beragam terutama yang tersedia di lingkungan sekitar. Tim pengabdi juga menyarankan untuk memanfaatkan lahan pekarangan untuk menanam sayuran dan buah-buahan.

Disamping itu, tim pengabdi juga membuat daftar kuesioner yang bertujuan untuk mengetahui sejauh mana manfaat dan tingkat pengetahuan peserta tentang topik yang diberikan baik sebelum maupun setelah kegiatan dilaksanakan. Dengan mengetahui jawaban dari kuesioner maka tim melakukan evaluasi sejauh mana dampak dari kegiatan ini sehingga dikemudian hari akan ada perbaikan yang lebih baik lagi. Daftar pertanyaan Kuesioner tersebut dapat dilihat pada tabel berikut :

Berdasarkan sebaran hasil pretestdan post-test yang dilakukan pada saat sebelum dan sesudah pelaksanaan penyuluhan terdapat peningkatan pengetahuan gizi masyarakat sasaran.Pengetahuan gizi dikategorikan baik jika nilainya $\geq 80$, sedang $60-79$, dan kurang $<60$ (Khomsan 2000).Dari hasil penilaian tersebut didapatkan hasil sebanyak $45 \%$ masyarakat sasaran memiliki pengetahuan gizi baik, 35\% memiliki pengetahuan gizi cukup, dan $20 \%$ memiliki pengetahuan gizi yang kurang. 
Saipul Al Sukri, dkk. Peningkatan pengetahuan gizi seimbang Dan mitos ...

Tabel 1. Pertanyaan pre-test dan post-test

\begin{tabular}{|c|c|c|}
\hline No & Pertanyaan & Jawaban \\
\hline 1 & Apakah Saudara mengetahui mengenai gizi seimbang? & $\begin{array}{l}\text { a. Ya } \\
\text { b. Tidak }\end{array}$ \\
\hline 2 & Apakah Saudara mengetahui mengenai 4 pilar gizi seimbang? & $\begin{array}{l}\text { a. Ya } \\
\text { b. Tidak }\end{array}$ \\
\hline 3 & $\begin{array}{l}\text { Apakak Saudara mengetahui mengenai perbedaan antara } 4 \text { sehat } 5 \\
\text { sempurna dengan pesan gizi seimbang? }\end{array}$ & $\begin{array}{l}\text { a. Ya } \\
\text { b. Tidak }\end{array}$ \\
\hline 4 & $\begin{array}{l}\text { Apakah Aktifitas Fisik, danperilaku hidup bersih dan sehat } \\
\text { merupakan bagian dari } 4 \text { pilar gizi seimbang }\end{array}$ & $\begin{array}{l}\text { a. Ya } \\
\text { b. Tidak }\end{array}$ \\
\hline 5 & Konsumsi Gula Pasir di batasi sehari masimal satu sendok the & $\begin{array}{l}\text { a. Ya } \\
\text { b. Tidak }\end{array}$ \\
\hline 6 & Disarankan berolahraga selama 30 menit 1 kali dalam seminggu & $\begin{array}{l}\text { a. Ya } \\
\text { b. Tidak }\end{array}$ \\
\hline 7 & $\begin{array}{l}\text { Konsumsi Minyak goreng di batasi sehari masimal empat sendok } \\
\text { makan }\end{array}$ & $\begin{array}{l}\text { a. Ya } \\
\text { b. Tidak }\end{array}$ \\
\hline 8 & Konsumsi Protein dianjurkan 1-2 porsi dalam sehari & $\begin{array}{l}\text { a. Ya } \\
\text { b. Tidak }\end{array}$ \\
\hline 9 & Menghindari Konsumsi alkohol merupakan pesan gizi seimbang & $\begin{array}{l}\text { a. Ya } \\
\text { b. Tidak }\end{array}$ \\
\hline 10 & $\begin{array}{l}\text { Tanggal Kadaluarsa merupakan satu satunya yang perlu diperhatikan } \\
\text { dalam makanan kemasan }\end{array}$ & $\begin{array}{l}\text { a. Ya } \\
\text { b. Tidak }\end{array}$ \\
\hline
\end{tabular}

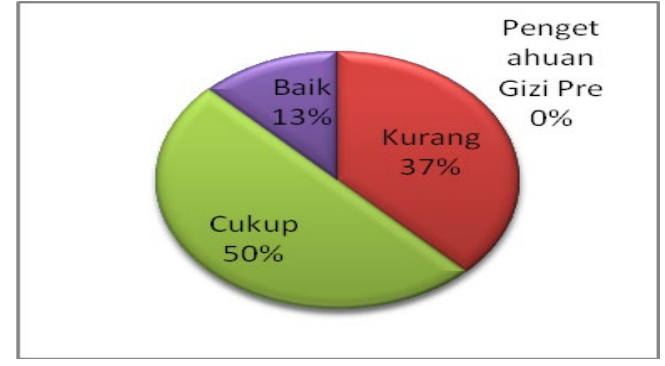

Gambar 1. Diagram Hasil Pre-test

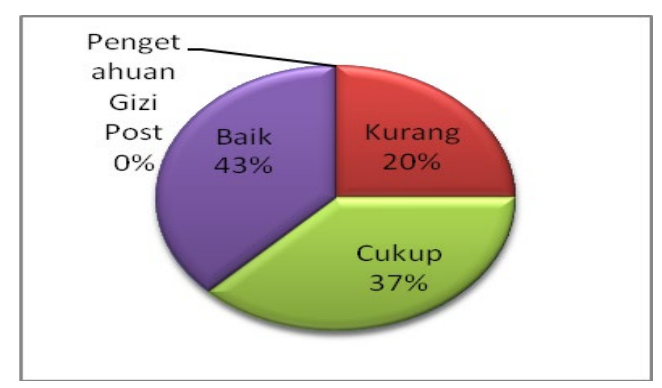

Gambar 2. Diagram Hasil Post-test

Tim pengabdi juga mengambil data berat badan dan tinggi badan mitra untuk melihat status gizi mereka melalui indeks massa tubuh (IMT).
Berdasarkan perhitungan IMT diperoleh hasil bahwa mayoritas mitra memiliki status gizi overweight $(60 \%)$ dan obesity (27\%). Hal ini diduga karena mitra belum menerapkan konsumsi makanan dengan gizi seimbang dan olahraga secara rutin. Obesitas perlu ditangani seperti mengubah pola hidup dan pola makan karena obesitas akan beresiko terhadap penyakit tidak menular di masyarakat seperti diabetes mellitus, hipertensi, dyslipidemia, jantung koroner, dan lainnya (Sudikno et al. 2015; Diana et al. 2013).

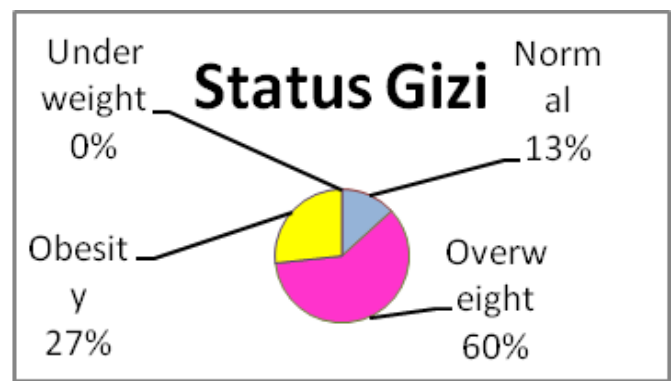

Gambar 3. Status Gizi Peserta 
Kegatan pengabdian diakhiri dengan sesi foto bersama dan tim pengabdi menyerahkan mini poster 10 pedoman gizi seimbang yang ditempelkan di ruangan pertemuan peserta PKH. Tujuannya agar peserta senantiasa bisa mengingat dan mempraktekkan pedoman gizi seimbang dalam kehidupan sehari-hari.

Berikut ini foto kegiatan pengabdian tersebut:

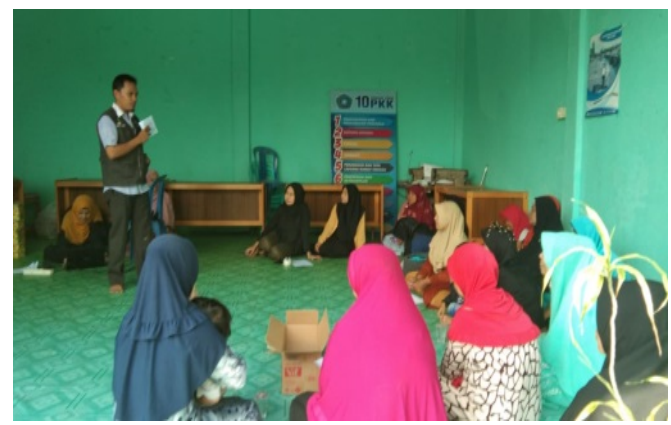

Gambar 4. Pembukaan acara dan pengisian form pre-test

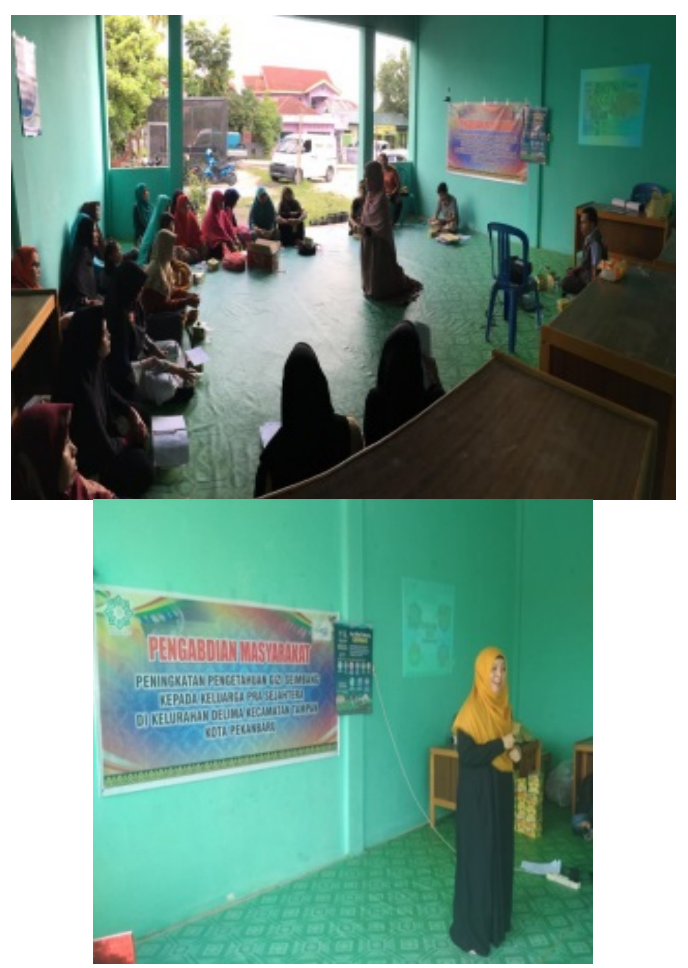

Gambar 5. Penyampaian materi dan tanya jawab dengan peserta.

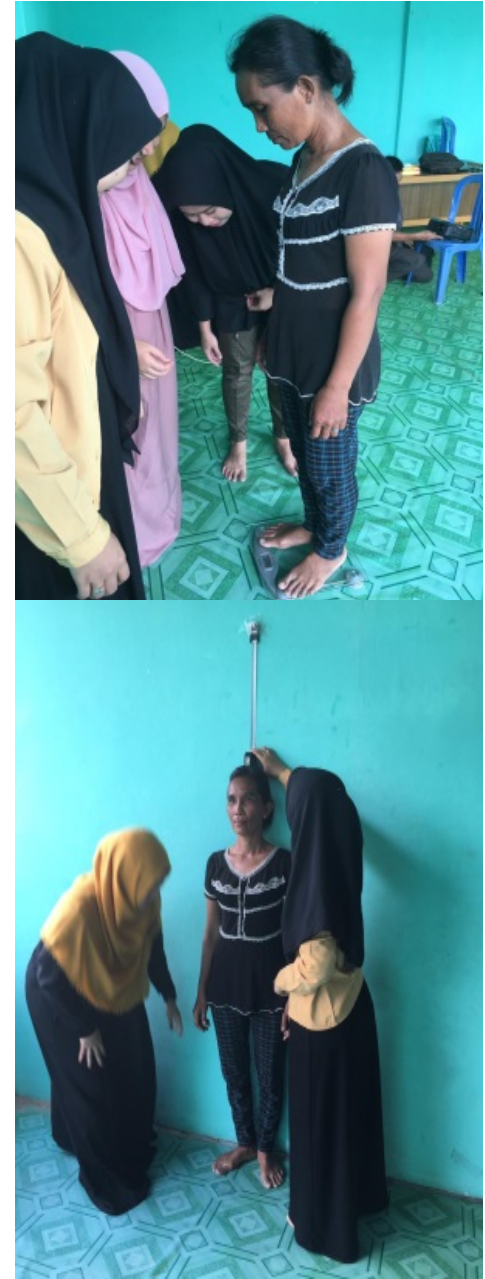

Gambar 6. Pengukuran antropometri berat dan tinggi badan peserta.

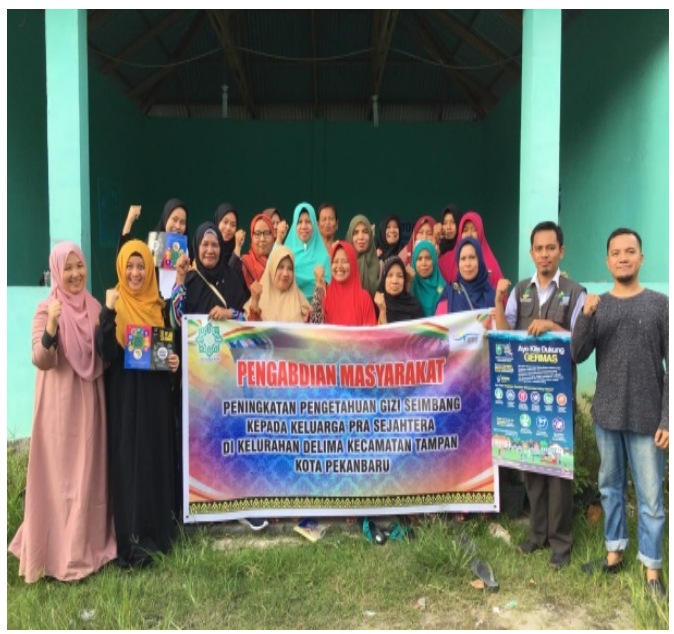

Gambar 7. Sesi foto bersama 
Saipul Al Sukri, dkk. Peningkatan pengetahuan gizi seimbang Dan mitos ...

SIMPULAN

Pengabdian masyarakat dengan topik "Peningkatan Pengetahuan Gizi Seimbang kepada Keluarga Prasejahtera di Kelurahan Delima, Kecamatan Tampan, Kota Pekanbaru" dapat berjalan dengan baik.Kegiatan yang dilakukan dapat menambah pengetahuan masyarakat tentang gizi seimbang.Masyarakat sasaran menyambut dengan baik dan berharap kegiatan ini dapat rutin dilakukan dengan topik yang berbeda-beda.

\section{UCAPAN TERIMA KASIH}

Terima kasih sedalam-dalamnya kami sampaikan kepada Lembaga Penelitian dan Pengambdian (LPPM) Universitas Islam Negeri Sultan Syarif Kasim Riau yang telah memberikan kesempatan kepada kami untuk melaksanakan kegiatan pengabdian ini. Selanjutnya kepada Sdr. Adi Kurniawan koordinator kecamatan Program Keluarga Harapan sebagai mitra pengabdi dalam kegiatan ini. Alhamdulillah kegiatan ini dapat terlaksana dengan baik.

\section{DAFTAR PUSTAKA}

De Porter Bobbi, Mark Reardon, \& Sarah Singer Nourie. 2010. Quantum Teaching. Bandung: Kaifa.

Almatsier S. 2005. Penuntun Diet Instalasi Gizi RS Cipto Mangunkusumo dan Asosiasi Dietisien Indonesia. Jakarta: PT. Gramedia Pustaka Utama.

Cordobo, 2010. Pola Makan Sehat, http://gayahidupsehat.org.

Diakses tanggal 15 Januari 2020.

Diana R, Yuliana I, Yasmin G, Hardinsyah. 2013. Faktor Risiko Kegemukan Pada Wanita
Dewasa Indonesia.Jurnal Gizi dan Pangan 8(1): 1-8.

Dirjen Bina Kesehatan Masyarakat, 2002. Buku Panduan 13 Pesan Dasar Gizi Seimbang, Jakarta.

https://databoks.katadata.co.id/ balitaindonesia-masih-mengalamimasalah-gizi.Diakses tanggal 23 Januari 2020.

https:/databoks.katadata.co.id/ 1-dari4-balita-mengalami-stuntingpada-2019.Diakses tanggal 23 Januari 2020.

Khensus, P, 2009. Ketika makanan sehat emakin langka, http://www.penulislepas.comDia ksen tanggal 10 Januari 2020.

Kementrian Kesehatan RI. 2003. Keputusan menteri Kesehatan RI No. 1098/Menkes/SK/VII/2003 Tentang Persyaratan Hygiene Sanitasi Rumah Makan dan Restoran, Jakarta.

Kementrian Kesehatan RI. 2018. Riset kesehatan Dasar Badan Litbang Kesehatan, Kementerian Kesehatan RI. Jakarta

Lucie, S, 2005. Teknik Penyuluhan dan Pemberdayaan Masyarakat, Penerbit Ghalia Indonesia, Bogor

Notoatmodjo, 2003.Komponenkomponen Pendidikan dalam Penyuluhan Kesehatan, FKM UI, Jakarta.

Sudikno S, Syarief H, Dwiriani CS, Riyadi H. 2015. Faktor Risiko Obesitas Sentral pada Orang Dewasa Umur 25-65 Tahun di Indonesia (Analisis Data Riset Kesehatan Dasar 2013).Jurnal Penelitian Gizi dan Makanan 38(2): 111-120.

Soekirman, 2002.Ilmu gizi dan aplilkasinya untuk keluarga dan masyarakat.Dirjen pendidikan tinggi, Departemen Pendidikan Nasional. Jakarta. 
Suhardjo, 2003. Berbagai Cara Pendidikan Gizi, Edisi 1, Penerbit Bumi Aksara, Jakarta.

Tursiani, A. 2010.Pengaruh penyuluhan gizi terhadap pengetahuan gizi ibi dan perubahan status gizi balita. Tesis: Program studi kedokteran keluarga program pasca sarjana Universitas sebelas maret. Surakarta. 